\title{
Tabulating Queer: Space, Perversion, and Belonging
}

\author{
Patrick Keilty \\ University of California, Los Angeles, Department of Information Studies, \\ GSE\&IS Building, Box 951520, Los Angeles, CA 90095-1520, USA \\ <pkeilty@gmail.com>
}

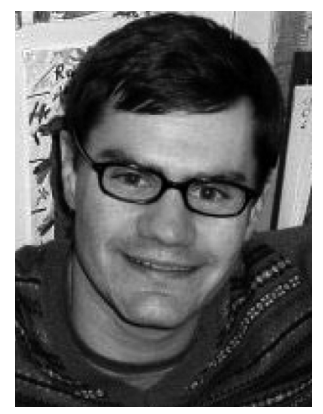

Patrick Keilty is a PhD candidate in the Department of Information Studies, with a concentration in the Women's Studies Department at UCLA. His research considers what differences feminism, gender studies, sexuality studies, and notions of queer, make to prevailing ideas about information structure, seeking, and ethics.

Keilty, P. Tabulating Queer: Space, Perversion, and Belonging. Knowledge Organization, 36(4), 240248. 21 references.

ABSTRACT: Considering fields as diverse as the history of science, Internet studies, border studies, and coalition politics, the article gives an historical overview of how the knowledge around queer phenomena has been structured, tabulated, and spacialized: the hazards, coercive and productive qualities, as well as queer's paradoxical relationship as both resistant to and reliant on categories, classification, and knowledge structures. In the process, the article also considers the development of Western hierarchical knowledge structures in relation to societal power dynamics, proximity, and space.

\section{Introduction}

As with border studies, "belonging" is a central concern in the study of classification, grouping things in relation to where they belong, where they don't belong, and why things belong in one class and not another. Yet not all phenomena belong neatly within a set of boundaries, as any cataloguer can attest, especially where classification systems meet the politics of ontologies, diverse ways of being. Queer is one such phenomenon, referring as it does to "the open mesh of possibilities, gaps, overlaps, dissonances and resonances, lapses and excesses of meaning when the constituent elements of anyone's gender, of anyone's sexuality aren't made (or can't be made) to signify monolithically" (Sedgwick 1993, 8). The term "queer" itself is an ever-shifting category to describe an area of study whose dimensions in recent years can't be subsumed under gender and sexuality alone: the ways it has been applied to race, ethnicity, post-colonial nationality, and transnationalism or other "identityconstituting, identity-fracturing discourses" (Sedgwick 1993, 9).
Nevertheless, much of the philosophical background of knowledge organization, such as systems philosophy, insists that general laws and principles underline all phenomena, allowing for its organization (Svenonius 2000, 3). Yet this assertion sounds mechanistic, teleological and monolithic: mechanistic because it assumes that phenomena have a system of predictable rules that interact to perform a function (in this case, their organization); teleological because it explains phenomena through purpose and design; and monolithic because it assumes phenomena can group wholly and singularly. Even Ludwig van Bertalanffy, the father of systems theory, acknowledged the limitations of such thinking. "This humanistic concern of general system theory as I understand it," writes Bertalanffy (1969, xxiii),

makes a difference to mechanistically oriented system theorists speaking solely in terms of mathematics, feedback and technology and so giving rise to the fear that system theory is indeed the ultimate step towards the mechanization and devaluation of man and towards technocratic so- 
ciety.... I do not see that these aspects can be evaded if general system theory is not limited to a restricted and fractional vision.

In the same work, Bertalanffy devotes an impressive chapter to the cultural relativism of categories. Indeed, a practice is by definition unsystematic without holistic, big picture thinking that includes, necessarily, consideration of humanistic concerns.

It is therefore instructive to examine the hazards involved in trying to find a classification system that can adequately organize queer phenomena-an inherently paradoxical phenomenon that by definition belongs to a category of that which does not belong-a phenomenon that is both dependent upon and resistant to borders, boundaries, categories, and classification-whose gravity (both the center and gravitas) is ever-shifting and misfit. Taking from Foucault's concept of order, one nevertheless sees how categorization of queer phenomena operates within bureaucratic discipline and how the creation of discernable categories is productive for institutional access. Simultaneously, organizing information about queer gender and sexuality has led, in some instances, to the eroticization of hierarchical knowledge structures and the systematization of sex and desire.

\section{Hazards}

To illustrate the hazards, let me begin by examining the classification system of a scholar noteworthy in the field of sexual science, Karl Heinrich Ulrichs (1825-1895). Ulrichs' work circulated widely in late nineteenth-century Europe. Homosexual men especially sought information that both explained and legitimized their sexual condition. His work, however, predated the term "homosexual" by several years. Instead, Ulrichs borrowed his nomenclature from Plato's Symposium, drawing a distinction between what he calls Uranian and Dionian love. Urnings, people who desire their own sex, express Uranian desire in the manner of the god Uranus. In contrast, according to Ulrichs, Dionings express Dionian desire, opposite-sex attraction, in the manner of the god Dione. His classification of desire becomes more complex as Ulrichs argues for the naturalness of Uranian desire. "There is," he writes, "a class of born Urnings, a class of individuals who are born with the sexual drive of women and who have male bodies." Ulrichs thus concludes that an Urning, "is not a man, but rather a kind of feminine being when it concerns not only his entire organism, but also his sexual feeling of love, his entire natural temperament, and his talents" (Ulrichs 1994, 36). On this basis, Ulrichs is able to create a new class of people, a third sex. According to Joseph Bristow, "since the sexed body and gendered mind are by definition turned inside out, Ulrichs declares the Urnings constitute a 'third sex': not fully men or women.' In making this claim, Ulrichs lays the ground on which he establishes the belief that Urnings are beings who contain the soul of the opposite sex in their own bodies" (Bristow 2003, 21). Bristow further explains (p. 22):

This idea would have lasting and damaging influence on twentieth-century prejudices against homosexuals. For it set the trend for imagining that lesbians and gay men were 'inverts'. One of the myths that has circulated most widely about lesbians and gay men is that both sexual identities involve the inversion of assumed gender norms - so that the butch lesbian and effeminate gay man have often been the recognizable stereotypes that serve to caricature and thus condemn styles of homosexual dissidence.

With further investigation, Ulrichs develops a fourth sex that corresponds to the third: "a sex of persons built like females having woman-womanly desire, i.e. having the sexual direction of men" (Ulrichs 1994, 81).

Yet the more Ulrichs investigated sexual behavior, the less he was able to classify the varieties of desire neatly in terms of Urnings and Dionings. For example, he eventually recognized what would later come to be known as bisexuality. And predictably, he created a category for bisexuals: Uranodionings. In time, Urlichs developed an elaborate classification system for people and their corresponding desires:

\begin{tabular}{|ll|}
\hline I. & Men \\
\hline II. & Women \\
\hline III. & Urnings \\
\hline & 1. Manlings \\
\hline & 2. Intermediaries \\
\hline & 3. Weiblings \\
\hline IV. & Urningins \\
\hline V. & Uranodionings \\
\hline & 1. Conjunctive \\
\hline & 2. Disjunctive \\
\hline VI. & Uranodioningins \\
\hline VII. Hermaphrodites (Ulrichs 1994, 314) \\
\hline
\end{tabular}

Table 1. Ulrichs' classification 
Ulrichs' system becomes less stable when we consider further assumptions made in the categories beyond the dichotomy of Uranian and Dionian desire. For example, Mannlings and Weiblings represent virile and effeminate homosexuals respectively, each internally opposed to each other, while Intermediaries belong to a category, which, according to Ulrichs, explains how a virile Urning takes a passive role in sex and an effeminate Urning takes an active role. His succeeding category, Urningins, designate a class later known in the early twentieth-century as lesbians, what Ulrichs refers to as 'woman-womanly' desire. Bisexuals fall into two categories: Conjunctive, who experience "sensual love in a double direction," and disjunctive, who "feel only a romantic gentle love for young men" (Ulrichs 1994, 313-14). Finally, Uranodioningins constitute female bisexuals while Hermaphrodites denote people whom Ulrichs observed having the physical characteristics of both sexes. It is important to note, too, the way in which Ulrichs conceives of sex and desire as split into two antithetical yet complementary forms: feminine always seeks masculine and passive always seeks active, whether Uranian or Dionian. However unwieldy and awkward Ulrichs' organization of knowledge about sexuality and desire looks, it is succinct compared to the classification systems of twentiethcentury encyclopedias of human sexuality, which reveal the great lengths to which social and medical scientists will go to comprehend sexual variety.

Furthermore, Ulrichs was not alone in investigating sex and desire in nineteenth-century Europe. Richard von Kraftt-Ebing takes as his theoretical model that all sexual love, even in its most praiseworthy married form, is to some degree tainted with illness; Iwan Bloch, far from believing that homosexuality is an illness, appraised sexual desire through medicine and scientific observation; and Otto Weininger, in contrast to many of his predecessors, believed that sex was always a matter of degree, rather than fixed opposition (though he also held the surprising belief that ideal types of men and women not only can be constructed but must be constructed, appealing to Platonic Idealism for his reasoning). Twentieth-century social and medical scientists, too, undertook to organize knowledge about sex and desire: from the classification of homosexuality as a mental illness by the American Psychological Association, and the subsequent pathologization of non-normative sexuality, to Alfred Kinsey's Sexual Nomenclature: A Thesaurus, still influential for organizing materials at the Kinsey Institute Library. Liana Zhao, head of the library at the Kinsey Institute, described the challenges of organizing and classifying its materials in her article "Characteristics of Material Organization and Classification in the Kinsey Institute Library," in part because sex generally had been a taboo topic for much of social history, queer sex even more so (Zhou 2003). Indeed, it is precisely because queer belongs to the categories of perversion that it transgresses the traditional boundaries of desire. In Ulrichs' time, homosexual desire was famously, in the words of Lord Alfred Douglass, "the love that dare not speak its name." So perverse was the desire that it resisted even ordinary categorical boundaries of explicit naming. Still the case, like Ulrichs' unwieldy tabulation of sexual categories, today's popular abbreviation "LGBT" is ever-expanding and cumbersome-not only for the sake of political inclusion, but also evidence that sex and desire do not signify monolithically. It derives from some variation of the following: $\mathrm{L}$ (esbian), $\mathrm{G}($ ay), $\mathrm{B}$ (isexual), $\mathrm{T}$ (ransexual), $\mathrm{T}$ (ransgender), $\mathrm{T}$ (ransvestite), $\mathrm{T}$ (wo-Spirited), $\mathrm{Q}$ (ueer), $\mathrm{Q}$ (uestioning), I(ntersex), $\mathrm{P}$ (ansexual), and so on. Moreover, categories such as "men who have sex with men" (MSM), which frequently refers to men who do not necessarily identify as gay or bisexual, group people into behavioral categories rather than identity categories, further showing the ways in which sex and desire do not yield easily to structures of categorization.

However hazardous the attempts have been to map knowledge about sex and desire-indeed, limiting how we are even able to think about these topics-the process has also been highly productive, marking the first of two paradoxical manifestations in the organization of queer phenomena. The other such paradox considers how queer necessarily relies on normalized and stabilized boundaries to exist, not only because queer itself is a category with limits-it is whatever normal sex and desire is not, that which does not belong, as normality changes over time-but also because queer transgresses those boundaries. Queer's non-normativity relies on norms as a precondition, and is therefore defined in relation to its opposite. This is a problem not easily remedied, if that is even a goal, but a debate about the dimensions of queer as a spacialized concept is not my concern here, though it is worth noting. Much more useful is an understanding of how the classification of queer phenomena has productive qualities that benefit queer subjects.

\section{Institutional Access}

It is important to remember that Ulrichs' research developed out of his lifelong radical campaign in 
Germany to justify and legitimize sexual relations between men and women. He did his utmost to defend "man-manly" and "woman-womanly" love as healthy and normal and to decriminalize them in German law. While his typology strikes us today as rather absurd, it was part of a broader effort that laid the groundwork for the modern lesbian and gay rights movement. His efforts have not gone unnoticed; The International Lesbian and Gay Law Association presents an annual Karl Heinrich Ulrichs Award in Ulrichs' memory. In fact, one forefront of queer legal scholarship and activism today concerns the classification of queer subjects in administrative law. For example, Dean Spade, in his article "Documenting Gender," investigates the conflicting gender (re)classification rules operating across the U.S. in departments of motor vehicles, public benefits systems, prisons, shelters, group homes, federal, state, and local data collection contexts to show the hazards of a national standardization and consolidation of identity documentation and data.

Despite examples of the coercive uses to which classification has been put, Spade strikes a middle ground regarding the attempts of administrative governance to classify, urging his readers: "It is imperative to neither uncritically embrace state caretaking projects as requiring growing levels of surveillance for purposes of security and health, nor to turn to individual privacy rhetoric wholeheartedly and valorize an end to government data collection" (Spade 2008, 819). As Spade indicates, debates surrounding the classification and data retention of HIV status concern the balance between privacy and the need for the distribution of resources to communities severely impacted by the disease. Taking from Bowker and Star $(2000,321)$, Spade advocates for a critical engagement with the categories of the powerful, realizing that "all information systems are necessarily suffused with ethical and political values."

Indeed, the relationship between power and classification is made complicated when the categorical regulation of subjects is required for institutional access. On the one hand, queer phenomena disrupt traditional sexual and gender categories, often rendering them unusable and thereby making sexual subjects impossible to identify, undermining the "discursive logic of homo and hetero," and "calling attention to heteronormativity rather than normalizing homosexuality" (Gamson 2003, 387). On the other hand, gay and lesbian activists today, like Ulrichs over one hundred years ago, are acting within, according to Gamson $(2003,387)$, "an institutional system that rewards interest groups and minorities whose boundaries are clear and immutable: stating over and over that the categories of homosexual and heterosexual are clear and natural and immutable, and that homosexuals are thus a discernable minority group deserving equal treatment." According to this logic, it is not simply that categories of sexuality regulate queer subjects or sex and desire more broadly. Rather, sexuality is "actively produced in organizations that have their own logics and exigencies, by people with jobs that have little directly to do with sexuality" (Gamson 2003, 388). Whether or not Ulrichs was aware of the instability of his categories of desire, the categories nevertheless helped achieve a certain degree of success in gaining queer men and women access to legal and political institutions in nineteenth-century Germany, however short-lived.

How, then, does one reconcile queer's resistance to classification with the institutional production to classify? After all, as I have shown, the consolidation of queer subjects into discernable categories necessarily normalizes the phenomenon, no longer rendering it queer. The problem is succinctly explained by Jagose (1996, 131): "Queer ... is an identity category that has no interest in consolidating or even stabilizing itself. It maintains its critique of identity-focused movements by understanding that even the formation of its own coalition and negotiated constituencies may well result in exclusionary and reifying effects far in excess of those intended." It is for this reason that the 1980s radical political group ACTUP has come to represent queer politics. It sought to coalesce around a particular moment, the AIDS emergency, and rethought identity in terms of affinity rather than essence, bringing together not only lesbians and gay men, but also bisexuals, transsexuals, sex workers, people with AIDS, health workers, parents and friends of gays, and many others effected by the disease. Its ironically named successor, Queer Nation, was almost exclusively a gay and lesbian organization, eventually fracturing its members even within those two categories, along axes of gender, desire, ethnicity, and color. As with Queer Nation, identity-based movements frequently (if not necessarily) stabilize identity by giving it cores and norms, thereby creating division where broader coalition is possible.

In the hopes of remedying this problem, Spivak (1995) developed the concept of 'strategic essentialism,' a strategy in which nationalities, ethnic groups or minorities temporarily 'essentialize' or stabilize themselves to achieve certain goals. Its power, therefore, lies in its temporality, instability, and the idea 
that things change over time, on the one hand, while simultaneously providing the stability and discernibility necessary for institutional access, on the other. It continually recognizes that essentializing is only strategic and does not reflect the reality of the phenomenon. Similar concepts are not entirely new to the classification of queer phenomena. In The Power to Name, Olson (2002) explores the limits of subject representations in library catalogs and argues for making the limits permeable without undermining limits altogether. She challenges the presumption that systems of classification and library subject headings are universally applicable. Yet the examples I provide reveal how correcting the hazards of classifying queer phenomena occurs not only when the structures of categorization are made permeable, but also when scholars, practitioners, and activists form a critical engagement congruent with queer's intrinsic resistance to classification. Otherwise, queer will have been sacrificed to an institutional system that rewards what it is not-a consolidated category.

\section{Difference and the Development of Western Hierarchical Knowledge Structures}

We have seen the ways in which categories of sex and desire are both coercive and productive. While categories perhaps limit how we are able to think about sex and desire, categorization also provides necessary institutional access. Yet, as I will show, the structure of the categories themselves developed out of a need to organize our society and those different from us, what Mudimbe calls "ordering the other." Thus, societal organization and social relations infuse the structure of categories, even while categories provide access to social organization and institutions. It is therefore instructive to consider how categories were used to create knowledge about subjects. Being the dominant model, Ulrichs necessarily relied on a traditional Western hierarchical knowledge structure for organizing desire, as is evidenced in the tabulation of his classification system above. Since the nineteenth-century, the concepts his categories represent have been deepened, broadened, and renamed, but the structure remains. To tabulate his subjects, Ulrichs used a scientific model received from the classifying rubrics of early modern science. Along with the naming, arranging, and ordering of plants and animals during the early modern period (the European Classical period) came the institutional systemization of classifying, as described by Foucault $(2007,143)$ :
It is often said that the establishment of botanical gardens and zoological collections expressed a new curiosity about exotic plants and animals. In fact, these had already claimed men's interests for a long while. What changed was the space in which it was possible to see them and from which it was possible to describe them. To the renaissance, the strangeness of animals was a spectacle: it was featured in fairs, in tournaments, in fictitious or real combats, in reconstitutions of legends in which the bestiary displayed its ageless fables. The natural history room and the garden, as created in the Classical period, replace the circular possession of the 'show' with the arrangement of things in a "table."

What Foucault describes $(2007,143)$ is the time between the age of the theatre and that of the catalog, which comes to fruition in the ever more complete systemization, preservation, and classification of things along an appropriate ordering by the nineteenth century:

The establishment of archives, then the filing systems for them, the reorganization of libraries, the drawing up of catalogues, indexes and inventories, all of these represent, at the end of the Classical age, not so much a new sensitivity to time, to its past, to the density of its history, as a way of introducing into the language already imprinted on things, and into the traces it has left, an order of the same type as that which was being established between living creatures.

Indeed, classification in the early modern period found itself constituted along an axis of where things-initially living things, later people-belonged naturally, creating of modern science, through the nineteenth century, a classified, squared and spacialized time.

Mudimbe makes explicit the ways in which the classifying rubrics of modern science, as described by Foucault, create and sustain social relations. $\mathrm{He}$ seeks to understand the ways in which nineteenthcentury Western colonizers and colonialists sought to epistemologically organize Africa by imposing on it Western knowledge structures, creating the foundations of Africanist discourse, and effectively organizing and transforming non-European areas into fundamentally European constructs. "Colonialism 
and colonization basically mean organization, arrangement. The two words derive from the Latin word colère, meaning to cultivate or to design" (Mudimbe 1988, 1). Taking from Foucault's concept that the center of knowledge was the principal of order in the European Classical age, Mudimbe understands the colonial organization of Africa-that is, "the dominance of physical space, of reformation of natives' minds, and the integration of local economic histories into the Western perspective"-from a hypothesis about the classification of being and societies (1988, 2 Mudimbe's italics). He writes, "It is the 'power-knowledge' of an epistemological field which makes possible a domineering and humbled culture" $(1988,11)$. Mudimbe considers how explicit political power presumes the authority of a scientific knowledge and vice-versa. Of this discourse, he writes, "Colonialism becomes its project and can be thought of as a duplication and fulfillment of the power of Western discourses on human varieties" $(1988,16)$. Tracing the lineage of the scientific model of anthropology, Mudimbe attempts to "account for the possibility of anthropological knowledge, and its meaning for the foundation of both Africanist discourses and African gnosis" $(1988,23)$.

Mudimbe asks us to consider issues derived from the allocation of an "African object" to nineteenthcentury anthropology. Portuguese sailors brought to Europe the first fetiços, African objects supposedly having mysterious powers, in the late fifteenthcentury. "One finds them mostly in well-organized curio cabinets, along with Indian tomahawks or arrows, Egyptian artifacts, and Siamese drums," writes Mudimbe (1988, 9-10). While some scholars consider these artifacts signs of barbarism, Mudimbe and others see then as simple curiosities brought back in accordance "with the tenth task of the travelers in the table of Verenius' Geographia generalis (1650): to consider "famous Men, Artificers, and Inventions of the Natives of All Countries" $(1988,10)$. Mudimbe argues that it is not until the eighteenth-century that these objects enter into the frame of African art, as strange and ugly artifacts. By the eighteenth-century, there was tremendous increase in the slave trade and trans-Atlantic economy, when European-sponsored organizations began to settle Africa, such that by 1792, Africans expelled the Portuguese in present-day Mozambique and by 1770, Dutch immigrants and Bantus began their first war. In this atmosphere of "intense and violent exchanges, fetiços became symbols of African art," creating a view of these once curious artifacts as "primitive, simple, childish, and nonsensical" (Mudimbe 1988, 10). Citing Baudrillard, Mudimbe argues that a process of aestheticization occurred from the eighteenth-century onward. "What is called savage or primitive art," writes Mudimbe, "covers a wide range of objects introduced by the contact between African and European during the intensified slave trade into the classifying frame of the eighteenth-century" $(1988,10)$. These objects were given an aesthetic character based on an artistic criterion and standard that emerged within the "powerknowledge" field of a given culture, designated, structured, arranged, and classified as "savage" objects.

As a scientist, Ulrichs is very much part of the scientific lineage of classification that Foucault and Mudimbe describe. Yet the social and power relations they describe also stem from a specifically hierarchical structure of Western knowledge that has ancient origins. The structure of Western knowledge developed in part by the change in Ancient Greece from an analogical structure of knowledge to a hierarchical one that resulted from attempts by Ancient Greeks to understand difference and social inequity. Indeed, attempts to "order the other" are not specific to modern science but in fact constitute, at least partly, the development of Western hierarchical knowledge structure and social organization, in the form of institutions. According to Page DuBois, "a fundamental crisis is brought on by the Peloponnesian War of 431-404, by subsequent social conflict within Athens, by returning prosperity and growing dependence on slavery. The new philosophy, as a hierarchizing, rational form of discourse, is born of these changes" (DuBois 1991, 2). Dubois investigates how the Greeks described the individual's existence in terms of the society of the Greeks' as a whole. She finds that before the Persian War, which ended in 478, Greeks often refer to those different than them in analogous terms. That is, "others" (barbarian, animal) "were like spokes radiating from the hub of a wheel" (DuBois 1991, 129). After the Persian War, Greek philosophers had to rationalize the existence of widespread slavery within Greek society and did so by turning away from seeing once analogous difference to seeing hierarchical difference. It was a theory of society bound up in Greek archaic cosmological theory, in which "the cosmic order is likened to a social or political order, to a living being, or to the product of "intelligent designing agencies" (DuBois 1991, 3).

By the time of the Peloponnesian War, the hierarchical view of individuals once reserved for Barbarians was enacted against fellow Hellenes. Not only were Greeks fighting other Greeks, once considered simi- 
lar to them, but there became a sharp distinction between those who had property and those who had none, resulting in a revolutionary clash. Indeed, "much of Plato and Aristotle's discourse concerned the problem of stasis, of civil war and conflict among people who would, in the fifth century, have thought themselves bound up in relations of similarity and community" (DuBois 1991, 131). Thus, Western hierarchical knowledge structure formed in trying to rationalize power differences among individuals in Greek society, and it continues to shape our thinking, organize our social relations, and serve as a model for our institutions more than two thousand years later.

\section{Eroticization of Hierarchical Knowledge Structure}

Ulrich's tabulation too reveals social power dynamics; the category "men," for example, maintains a privileged status "on top" and is defined by a group of people who desire the opposite sex. Yet these same dynamics can be seen even within contemporary information seeking spaces and institutions, especially online, where the hierarchical structures of sex and desire are made erotic. Consider, for example, the arrangement of sexual desires on adult video hosting services online, such as Xtube.com, which allows individuals to upload pornographic video clips, basically Youtube for pornography.

On the one hand, Xtube attempts to provide a near instantaneous mass mediation and dissemination of sexual representation. Conceivably, one might argue that this wealth of images offers an emancipatory scenario whereby subjects can project their virtual selves into a seemingly endless variety of environments, and to embody an infinite number of freely chosen subject positions, roles and desires. Additionally, one might argue that Xtube allows for an exploration of the self and one's identity in relation to others (indeed, reliant on others as viewers). In this sense, Xtube creates new possibilities for various stylistics of the self, where the self is a work in progress, an artist of itself. According to David Halperin, such autonomy of the self creates a new strategic possibility by making the self a public site (Halperin 1995, 72). Thomas Laqueur, in his look at the history of masturbation, argues that the Internet frees people's desires and fantasies from disciplining voices. He claims that as a result of the Internet, "masturbation has become not only a source of individual self-discovery and the celebration of the imagination and its infinite possibilities, but also the basis for a new form of sexual sociability rooted in the celebration of the imagination and its infinite possibilities" (Laqueur 2003, 419). He continues:

There are hundreds of thousands of pornographic sites that cater to every masturbatory fantasy imaginable, but what is really new is the virtual communities of onanists, an alternate universe of sociability that is created through the public revelation of the not so vice. Cyberspace has ... made possible an erotic community whose desires are not so easily brought within the bounds of power as they were constituted in or around 1712.

Indeed, in many ways, Xtube breaks down notions of public and private. Because most of the images on Xtube are home-made, though certainly not all, they are recorded in a space often conceived in the West as archetypal of privacy. Yet in the case of Xtube, the private space and sexual acts are being publicly broadcast and then (presumably) privately consumed, thereby complicating the private/public divide, a boundary that is ever shifting online.

On the other hand, Xtube's classifications function to guide, if not overtly discipline, subjects-both the subjects of the images and the viewer as subject. It is evidence of an environment in which desires and subject positions are produced as essential standards through a discourse of hierarchal categorization and classification. Images on Xtube are available to the viewer only through the negotiation of a coarse and elaborate typology in which subject positions are fixed and defined in relation to each other, similar to Ulrichs' tabulation. For example, the tags "boy" and "boi" - the latter term Judith Halberstam (2006, 114) has defined as a "boyish gay man"-often depict subjects performing receptive roles in sex, which Ulrichs had categorized as effeminate and passive. Like Ulrichs, the word "man" is not applied to the receptive subject position. The subject is often paired with a person in the insertive sexual role, who is seemingly older or more masculine or both. Thus, the categories applied to this erotic image maintain Ulrichs' tabulation of "Men" as a separate and distinct category from those who take a receptive role in sex. In that formation, sex and desire are conceived along an antithetical axis in which feminine pairs with masculine and passive with active. This classification scheme is common throughout Xtube. Consider, as well, how the hierarchical classification reveals itself among the images labeled "BDSM" (Bondage, Discipline, Sa- 
dism, Masochism). Among these images, the seemingly dominant and active person in sex, the one inflicting pleasure/pain, is often tagged as a "man," a "master," or even a "real man," whereas the seemingly passive person in sex is referred to as a "boy" or "slave." In this way, the power dynamics of the hierarchical structure are made explicit, as well as erotic. The phenomenon is also noticeable among subcultural BDSM dating sites, in which users apply these categories to themselves, thereby embracing the eroticized hierarchy.

While a user might role-play within these categories, the "exploration" is always already constrained by a logic of recognizable cues that are regularized, disciplined and stabilized according to norms of sex and desire that have long been reflected in the organization of these topics. In the case of Xtube, users are required to organize their images among standardized "channels" that prioritize certain categories within which users make a priori decisions about how to tag. Indeed, users are not connected to their desires through categorization so much as their desires are already named, regulated, and stabilized in advance, along a coarse axis of registers. Because the identity of their desires belongs within discernable boundaries, so too is the perception that desire is stable. Whether or not their desires transgress these boundaries, subjects are forced to choose from among the categories in order both to satisfy their desire and to name themselves to others as a desiring subject. The same was true of Ulrichs' tabulation; homosexual men in the nineteenth-century looked to his typology to identify themselves, partly for legitimization, partly for self-understanding, and partly to develop a nomenclature necessary to connect to others.

Yet this regulation does not occur only online. It is also evidenced in Sharon Olds' poem "The Solution," first published in 1987, in which she critiques, among other sexual aspects of our culture, the categorical systemization of desire. A phrase from the last line is especially fitting, "since they had to name it," reflecting our need for distinctions (italics my own). On the one hand, without such categories, subjects would not access those who share their desire. On the other hand, these categories of desire function to regulate subjects - grouping them where they belong, where they don't belong - and reinscribes social relations. Consider the following two excerpts, "but the line for $38 D$ or Bigger was getting unruly, shouting insults at the line for 8 Inches or Longer" and "people under the sign I Like to Give Pain paired up with a steady stream of people from under I Like to Receive Pain."
Both of these lines reveal not only the ways in which categories have come to constitute identities of desire-identities that allow one to belong to one group or another-but also the ways in which social relations-in this case, of conflict and power dynamics respectively-are wrapped up in eroticized categories. Thus, categories of desire allow access to one's desires, regulate one's desires, and reinscribe the very social organization that is necessary for both institutional access and belonging. I present Old's poem (1987, 17-18) in its entirety:

Finally they got the Singles problem under control, they made it scientific. They opened huge Sex Centers-you could simply go and state what you want and they would find you someone who wanted that too. You would stand under a sign saying I Like to Be Touched and Held and when someone came and stood under the sign saying I Like to Touch and Hold they would send the two of you off together.

At first it went great. A steady stream of people under the sign I Like to Give Pain paired up with a steady stream of people from under $I \mathrm{Li}$ ke to Receive Pain. Foreplay Only-No Orgasm found its adherents, and Orgasm Only-No Foreplay matched up its believers. A loyal Berkeley, California, policeman stood under the sign Married Adults, Lights Out, Face to Face, Under a Sheet, because that's the only way it was legal in Berkeley-but he stood there a long time in his lonely blue law coat. And the man under I Like to Be Sung to White Bread Is Kneaded on My Stomach had been there weeks without a reply.

Things began to get strange. The Love Only-No Sex was doing fine; the Sex Only-No Love was doing well, pair after pair walking out together like wooden animals off a child's ark, but the line for $38 D$ or Bigger was getting unruly, shouting insults at the line for 8 Inches or Longer, and odd isolated signs were springing up everywhere, $R e$ tired Schoolteacher and Parakeet-No Leather; One $\mathrm{Rm} /$ No Bath/View of Sausage Factory.

The din rose in the vast room. The line under $I$ Want to Be Fucked Senseless was so long that portable toilets had to be added and a minister brought for deaths, births, and marriages on the line. Over under I Want to Fuck Senseless-no one, a pile of guns. A hollow roaring filled the 
enormous gym. More and more people began to move over to Want to Be Fucked Senseless. The line snaked around the gym, the stadium, the whole town, out into the fields. More and more people joined it, until Fucked Senseless stretched across the nation in a huge wide belt like the Milky Way, and since they had to name it they named it, they called it the American Way.

\section{Conclusion}

As this overview shows, classification has both coercive and productive effects for queer. Ulrichs' tabulation of sex and desire reveals long lasting hierarchical social relations that continue to infuse contemporary information spaces. Problematizing the hazards of classifying queer phenomena occurs not only when the structures of categorization are made permeable, but also when scholars, practitioners, and activists form a critical engagement congruent with queer's intrinsic resistance to classification. Otherwise, queer will have been sacrificed to an institutional system that rewards what it is not-a consolidated identity category. Future scholarship must exam the relationship between Western hierarchical knowledge structures and social power dynamics, as well as the formative power of knowledge structures on our understanding and social relations.

\section{References}

Bertalanffy, Ludwig van. 1969. General system theory: foundations, development, applications. New York: George Braziller.

Bowker, Geoffrey C. and Star, Susan Leigh. 2000. Sorting things out: classification and its consequences. Cambridge, MA: MIT Press.

Bristow, Joseph. 2003. Sexuality. New York: Routledge.

DuBois, Page. 1991. Centaurs and Amazons: women and the pre-bistory of the great chain of being. Ann Arbor: University of Michigan Press.

Foucault, Michel. 2007. The order of things: an archaeology of human sciences. New York: Routledge.

Gamson, Joshua. 2003. Reflections on queer theory and communication. In Yep, Gust, et al. eds.,
Queer theory and communication: from disciplining queers to queering the discipline(s). New York: Haworth Press.

Gellner, Ernest. 1998. Language and solitude. Cambridge: Cambridge University Press.

Halberstam, Judith. 2006. Boys will be... bois?: Or, transgender feminism and forgetful fish. In Richardson, Diane, et al. eds., Intersections between feminist and queer theory. New York: Palgrave Macmillan.

Halperin, David. 1995. Saint = Foucault: towards a gay hagiography. Oxford: Oxford University Press.

Jagose, Annamarie. Queer theory: an introduction. New York: New York University Press.

Laqueur, Thomas. 2003. Solitary sex: a cultural history of masturbation. New York: Zone Books.

Mudumbe, V. Y. 1988. The invention of Africa: gnosis, philosophy and the order of knowledge. Bloomington, IN: Indiana University Press.

Olds, Sharon. 1987. The gold cell. New York: Knopf.

Olson, Hope. 2002. The power to name: locating the limits of subject representation in libraries. Boston: Kluwer Academic Publishers.

Sedgwick, Eve Kosofsky. 1993. Tendencies. Durham: Duke University Press.

Spade, Dean. 2008. Documenting gender. Hastings law journal 59: 731-842.

Spivak, Gayatri Chakravorty. 1995. The Spivak reader: selected works of Gayatri Chakravorty Spivak. New York: Routledge.

Svenonius, Elaine. 2000. The intellectual foundation of information organization. Cambridge, MA: MIT Press.

Ulrichs, Karl Heinrich. 1994. The riddle of "manmanly" love: the pioneering work on male bomosexuality, 2 vols., trans. Michael A. Lombardi-Nash. New York: Prometheus Books.

Xtube.com 2008. Retrieved August 28, 2008, from http://wiki.xtube.com/index.php?title =XTube\& action=purge\#Statistics_and_Growth

Zhao, Liana. 2003. Characteristics of material organization and classification in the Kinsey Institute Library. Cataloging and classification quarterly 35no.3/ 4: 335-53. 